\title{
Assessment and forecast of technological requirement for flax harvesting machinery with conditional coefficients
}

\author{
Aleksandr Lavrov ${ }^{1, *}$, Maksim Moskovskiy ${ }^{1}$, Andrey Boiko $^{2}$, Lyudmila Godunova ${ }^{2}$ and \\ Hoang Ngia Dat ${ }^{3}$ \\ ${ }^{1}$ Federal Scientific Agro-Engineering Center VIM, 1 Institutsky proezd, 5, Moscow, 109428, Russia. \\ ${ }^{2}$ Don State Technical University, Gagarin Square, 1, Rostov-on-Don, 344000, Russia. \\ ${ }^{3}$ Hanoi University of Agriculture, Hanoi, Vietnam.
}

\begin{abstract}
As a result of the analysis of the production and status of the fleet of flax harvesting machinery, negative problems with the machines of farms of different types were revealed. The extensive statistical material on the dynamics of changes in flax production indicators has been generalized. Conditional (reference) coefficients have been investigated and refined. The technological need for specialized flax harvesting equipment and its forecast for meeting Russia's demand for flax fiber have been determined.
\end{abstract}

\section{Introduction}

One of the main problems of flax production in Russia is low production efficiency due to insufficient material and technical equipment and the associated disruption of the technological process $[1,2]$. Due to the shortage of specialized flax harvesting machines, the agro-terms of harvesting work are violated, which leads to a decrease in the quantity and quality of the obtained flax fiber. This situation requires the adoption of emergency government measures of state support aimed at the development of production of modern domestic flax harvesting equipment.

The aim is to calculate the normative requirement for flax harvesting equipment using the coefficients for converting physical units of equipment into reference units, which makes it possible to assess the potential efficiency of their fleet, taking into account the main indicators of the technical level.

\section{Materials and methods}

Dynamic of changes in flax production indicators in agricultural organizations (AO) of Russia for 1992-2019 is presented in table $1[3,4]$.

\footnotetext{
* Corresponding author: tomasss1086@mail.ru
} 
Table 1. Main indicators of flax production in agricultural enterprises of Russia for 1992-2019

\begin{tabular}{|l|c|c|c|c|c|c|c|c|c|}
\hline \multirow{2}{*}{ Indicators } & \multicolumn{9}{|c|}{ Years } \\
\cline { 2 - 10 } & $\mathbf{1 9 9 2}$ & $\mathbf{2 0 0 0}$ & $\mathbf{2 0 0 5}$ & $\mathbf{2 0 1 0}$ & $\mathbf{2 0 1 5}$ & $\mathbf{2 0 1 6}$ & $\mathbf{2 0 1 7}$ & $\mathbf{2 0 1 8}$ & $\mathbf{2 0 1 9}$ \\
\hline $\begin{array}{l}\text { Amount of flax } \\
\text { harvesters, } \\
\text { thousand units }\end{array}$ & 8,5 & 3,2 & 1,8 & 0,7 & 0,4 & 0,3 & 0,3 & 0,3 & 0,2 \\
\hline $\begin{array}{l}\text { Combine load, ha } \\
*\end{array}$ & 28,8 & 27,3 & 46,7 & 52,3 & 96,2 & 109,9 & 97,8 & 99,6 & $\begin{array}{c}166, \\
7\end{array}$ \\
\hline $\begin{array}{l}\text { Equipment, unit / } \\
1000 \text { ha * }\end{array}$ & 34,7 & 36,7 & 21,4 & 19,1 & 10,4 & 9,1 & 10,2 & 10,0 & 6,0 \\
\hline $\begin{array}{l}\text { Flax fiber } \\
\text { production, } \\
\text { thousand tons }\end{array}$ & 76 & 48 & 53 & 30 & 35 & 31 & 27 & 26 & 29 \\
\hline $\begin{array}{l}\text { Sowing area, } \\
\text { thousand ha * }\end{array}$ & 245,2 & 87,3 & 84,1 & 36,6 & 38,5 & 33,0 & 29,3 & 29,9 & 33,3 \\
\hline $\begin{array}{l}\text { Yield, kg / ha (all } \\
\text { households) }\end{array}$ & 310 & 550 & 630 & 820 & 910 & 940 & 920 & 870 & 870 \\
\hline
\end{tabular}

* calculated data

The data in Table 1 on the change in the amount of combines and the equipment of the cultivated areas are presented graphically (Fig. 1,2).

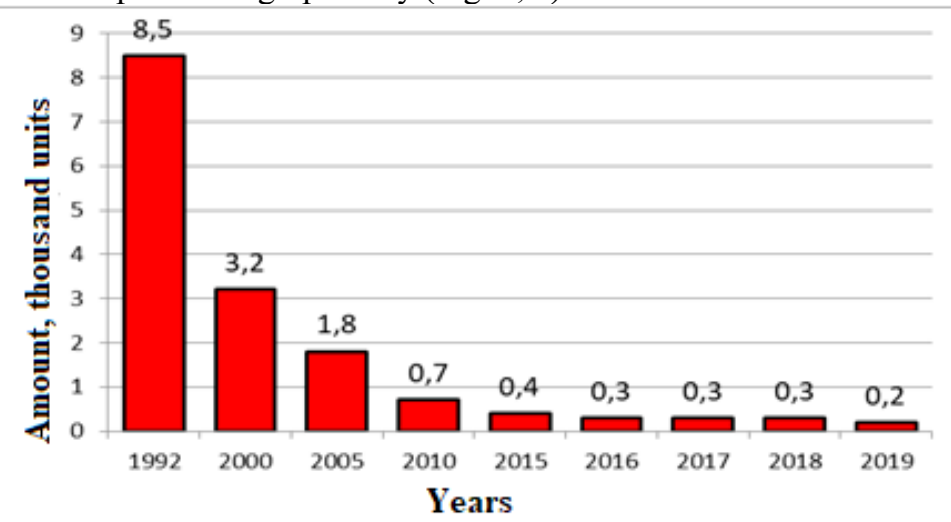

Fig. 1. Dynamic of changes in the amount of flax harvesters in agricultural enterprises of Russia for 1992-2019

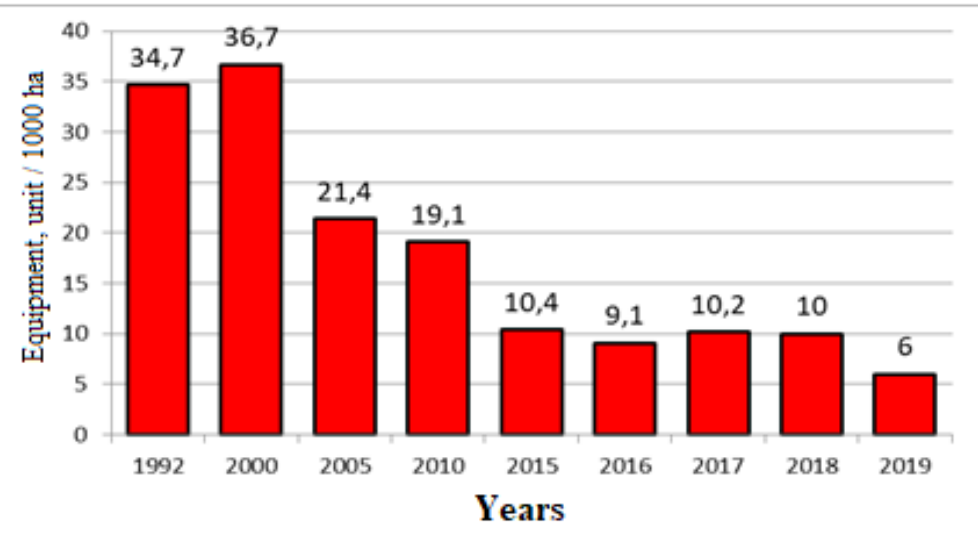

Fig 2. Dynamics of changes in equipment with combines in agricultural enterprises of Russia for 1992-2019 
As we see from Figure 1 for the period from 1992-2019, the number of flax harvesters was reduced from 8500 to 200 units (by 42.5 times) in the Russian agricultural sector, which leads to a reduction in the sowing area of flax and the production of flax fiber in general. At the same time, the equipment with combines per 1000 hectares of sown areas (Fig. 2) decreased from 34.7 to 6 units / 1000 hectares (5.8 times), which causes additional crop losses due to a violation of the agricultural period of harvesting.

First of all, the reduction in the fleet of flax harvesting machines is caused by a reduction in production (Table 2) ) [5] where:

LK-4A is flex harvester type 4, tractor-hitched;

LK-4D is flex harvester type 4 modernized, tractor-hitched;

LTS-1,65 is flex-pulling machine, self-propelled with capture width 1,65 m;

Dvina $4 \mathrm{M}$ is foreign flex harvester modernized, tractor-hitched;

MTL-1,5 is flex-pulling equipment, tractor-hitched;

TLP-1,5K is flex-pulling machine type 4, tractor-hitched;

Table 2. Production of flax harvesting machines in Russia in 2004-2019

\begin{tabular}{|c|l|l|c|}
\hline \multicolumn{1}{|c|}{ Year } & \multicolumn{1}{|c|}{ Manufacturing company } & \multicolumn{1}{|c|}{ Model } & Quantity, unit \\
\hline 2004 & CJSC "Plant Bezhetskselmash" & LK-4A & 251 \\
\hline 2005 & CJSC "Plant Bezhetskselmash" & LK-4A & 100 \\
\hline 2006 & CJSC "Plant Bezhetskselmash" & $\begin{array}{l}\text { LK-4A } \\
\text { LK-4D }\end{array}$ & 30 \\
& & - & 20 \\
\hline 2007 & - & $\begin{array}{l}\text { LTS-1,65 } \\
\text { (LK-4A) }\end{array}$ & 0 \\
\hline 2008 & "Tverselmash" & - & 10 \\
& & - & 0 \\
\hline 2009 & - & Dvina 4M & 8 \\
\hline 2010 & - & & 0 \\
\hline 2011 & "Cherepovets Foundry and & - & 0 \\
& Mechanical Plant" (ChLMZ) JSC, & 0 \\
\hline 2012 & - & - & 0 \\
\hline 2013 & - & - & 1 \\
\hline 2014 & - & - & 4 \\
\hline 2015 & - & - & 15 \\
\hline 2016 & - & MTL-1,5 & 0 \\
\hline 2017 & Omsk Experimental Plant & TLP-1,5K & 0 \\
\hline 2018 & LLC "TexInzh", Ivanovo & TLP-1,5K & 0 \\
\hline 2019 & LLC "TexInzh", Ivanovo & & 0 \\
\hline
\end{tabular}

Dynamic of production of flax harvesting machines in Russia for the period 2005-2019 is shown in Figure 3. 


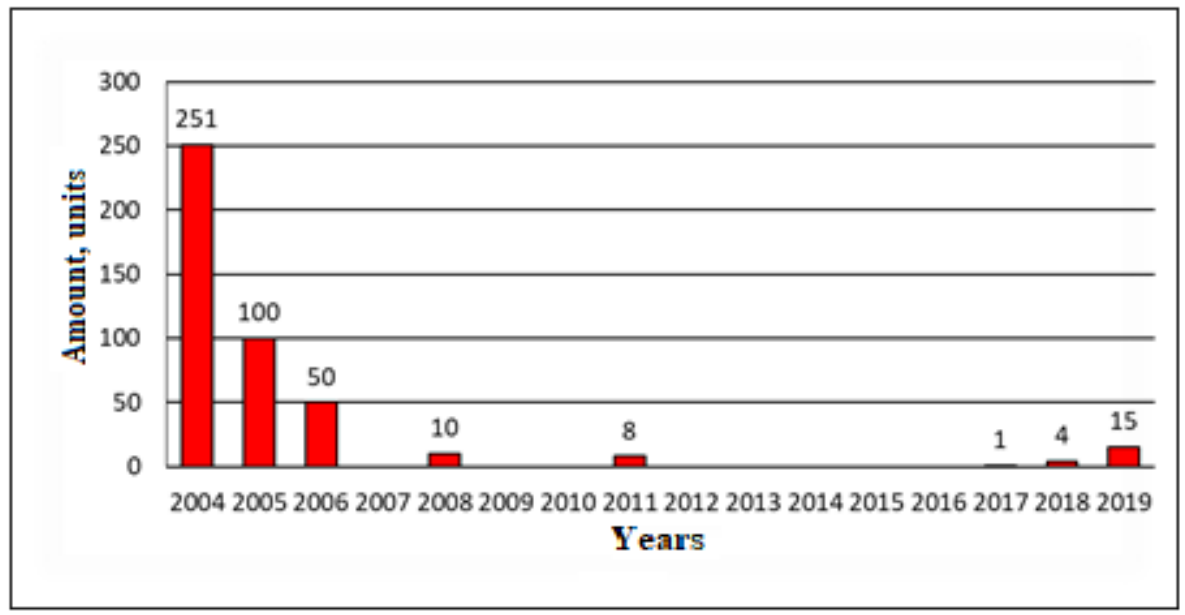

Fig 3. Production of flax harvesting machines in Russia in 2004-2019

As we can see from Fig. 3, the production of flax harvesting machines has practically stopped on the territory of the Russian Federation, in this regard, the dependence on foreign machines increases and the production of flax fiber in Russia is threatened.

The calculation of the standards (Table 3 ) for the need for flax harvesting machines is based on perspective technological maps of flax production, providing for the implementation of all operations in optimal agro-terms, as well as the distribution of work volumes between agricultural machines, which ensures their rational loading during of the year [6-8].. The primary optimization was carried out on line charts, thanks to which the intense periods were identified and their scope of work was highlighted. The standards are calculated taking into account the soil and climatic conditions for the model farms of each agrozone. In addition, a large amount of information was summarized on the actual need of agricultural organizations for specialized machines for harvesting flax.

Table 3. Requirements for equipment for harvesting fiber flax in reference units

\begin{tabular}{|c|c|c|c|c|c|c|c|}
\hline \multirow[t]{2}{*}{ Federal district } & \multirow{2}{*}{$\begin{array}{l}\text { Agroz } \\
\text { one }\end{array}$} & \multicolumn{6}{|c|}{ Per 1000 ha of crops } \\
\hline & & $\begin{array}{c}\text { Flax-pulling } \\
\text { machines }\end{array}$ & $\begin{array}{c}\text { Flax } \\
\text { thresher }\end{array}$ & $\begin{array}{l}\text { Harve } \\
\text { sters }\end{array}$ & Agitator & Turner & $\begin{array}{c}\text { Picker } \\
\text { S }\end{array}$ \\
\hline Central & 1.1 & 10,0 & 18,8 & 25,0 & 9,1 & 9,1 & 11,6 \\
\hline North-western & 2.1 & 10,1 & 18,8 & 25,0 & 9,1 & 9,1 & 11,6 \\
\hline \multirow[t]{3}{*}{ Privolzhsky } & 4.1 & 8,0 & 18,5 & 25,2 & 9,1 & 9,1 & 10,8 \\
\hline & 4.2 & 8,0 & 18,7 & 25,0 & 9,1 & 9,1 & 11,6 \\
\hline & 4.3 & 8,0 & 18,8 & 25,2 & 9,3 & 9,3 & 11,7 \\
\hline \multirow[t]{2}{*}{ Ural } & 5.1 & 8,3 & 18,8 & 25,2 & 9,3 & 9,3 & 11,7 \\
\hline & 5.2 & 8,4 & 18,1 & 24,8 & 9,6 & 9,6 & 11,5 \\
\hline Siberian & 6.1 & 8,2 & 18,1 & 24,8 & 9,6 & 9,6 & 11,5 \\
\hline $\begin{array}{l}\text { Russia } \\
\text { general }\end{array}$ & & 9,3 & 18,7 & 25,0 & 9,1 & 9,1 & 11,6 \\
\hline
\end{tabular}




\section{Research results}

The sowing area of fiber flax was 45 thousand hectares in all categories of farms in 2018 . In agricultural organizations, it was equal to 36 thousand hectares. On farms, flax was cultivated on 9 thousand hectares. The flax yield was $8.7 \mathrm{~kg} /$ ha in 2018 .

The total amount of combines was 200 units in agricultural organizations in 2018, organizations there were only 40 units of combines in farms.

Initial data: the area under crops is 36 thousand hectares, the normative requirements of combines per 1000 hectares of sowing area is 25.0 standard units, a conventional coefficient of 1.2 (technical level).

36 thousand hectares $\cdot 25.0=900$ standard units

In physical units: $\frac{900}{1.2}=750$ units

For farms, the need for combines will be as follows: 9 thousand hectares $\cdot 25.0=$ 225 standard units

In physical units: $\frac{225}{1.2}=188$ units.

Using a similar methodology, the technological need for all flax harvesting equipment was calculated (Table 4).

Table 4. Technological requirement for flax harvesting machines in 2018

\begin{tabular}{|c|c|c|c|c|c|c|c|c|}
\hline \multirow{2}{*}{$\begin{array}{c}\text { Federal } \\
\text { district }\end{array}$} & \multirow{2}{*}{$\begin{array}{l}\text { Agro } \\
\text { zone }\end{array}$} & \multirow[b]{2}{*}{$\begin{array}{l}\text { Sowing } \\
\text { area } \\
\text { thousan } \\
\text { d ha }\end{array}$} & \multicolumn{6}{|c|}{ Total amount of combines, units } \\
\hline & & & $\begin{array}{c}\text { Flax- } \\
\text { pulling } \\
\text { machine } \\
\text { s }\end{array}$ & $\begin{array}{c}\text { Flax } \\
\text { threshe } \\
\text { r }\end{array}$ & $\begin{array}{c}\text { Harvester } \\
\text { s }\end{array}$ & $\begin{array}{l}\text { Agitato } \\
\mathbf{r}\end{array}$ & $\begin{array}{c}\text { Turne } \\
\mathbf{r}\end{array}$ & $\begin{array}{c}\text { Picker } \\
\text { s }\end{array}$ \\
\hline Central & 1.1 & 11,92 & 99 & 187 & 248 & 90 & 90 & 115 \\
\hline $\begin{array}{l}\text { North- } \\
\text { western }\end{array}$ & 2 & 4,96 & 42 & 78 & 103 & 38 & 38 & 48 \\
\hline \multirow{3}{*}{$\begin{array}{l}\text { Privolzhsk } \\
\text { y }\end{array}$} & 4.1 & 3,04 & 20 & 47 & 64 & 23 & 23 & 27 \\
\hline & 4.2 & 0,88 & 6 & 14 & 18 & 7 & 7 & 9 \\
\hline & 4.3 & 3,44 & 23 & 54 & 72 & 27 & 27 & 34 \\
\hline \multirow[t]{2}{*}{ Ural } & 5.1 & 0 & 0 & 0 & 0 & 0 & 0 & 0 \\
\hline & 5.2 & 3,04 & 21 & 46 & 63 & 24 & 24 & 29 \\
\hline Siberian & 6.2 & 8,56 & 58 & 129 & 177 & 68 & 68 & 82 \\
\hline $\begin{array}{l}\text { Russia in } \\
\text { general }\end{array}$ & & 35,84 & 270 & 554 & 746 & 277 & 277 & 344 \\
\hline
\end{tabular}

Forecast of technological requirement for flax harvesting equipment

The sown area of fiber flax in 1992 was 327 thousand hectares. In subsequent years, these areas decreased and in 2016 there were only 50.8 thousand hectares. in all categories of farms. In agricultural organizations, it was equal to 39.2 thousand hectares. Flax was cultivated on farms on 11 thousand hectares. Flax yield in 1992 was $3.1 \mathrm{c} / \mathrm{ha}$, and in 2016 it increased threefold and amounted to $9.4 \mathrm{c} / \mathrm{ha}$. In 1992, there were 27 harvesters per 1000 hectares, and in 2016 there were 13 units, a decrease by half. The load per combine was 38 hectares of sown areas, in 2016 it was already 75 hectares. However, this did not affect the yield of this crop.

The total amount of harvesters in 1992 was 8.5 thousand units, and in 2016, 500 units worked in agricultural organizations, and 100 units of combines worked on farms. 
Considering that fiber flax is a strategic crop, but at the same time very labor-intensive and costly, with its need of 350 thousand tons and an average yield of $10-12 \mathrm{~kg} / \mathrm{ha}$, it will presumably be cultivated on 300,000 hectares, which is approximately equal to the area of fiber flax in 1992. Taking this into account, it is possible to calculate the predicted technological need for combines for the future. Initial data: the area under crops is 300 thousand hectares, the standard requirement of combines per 1000 hectares of the sown area is 25.0 reference units, the conditional coefficient is 1.2 (technical level).300 thousand hectares $\cdot 25.0=7500$ standard units.

In physical units: $\frac{7500}{1.2}=6250$ units

For farms, the need for combines will be as follows: 50 thousand hectares $\cdot 25.0=$ 1250 standard units.

In physical units: $\frac{1250}{1.2}=1042$ units

Using a similar methodology, the predicted technological demand for all flax harvesting equipment was calculated (Table 5).

Table 5. Forecast of technological demand for flax harvesting equipment

\begin{tabular}{|c|c|c|c|c|c|c|c|c|}
\hline \multirow{2}{*}{$\begin{array}{c}\text { Federal } \\
\text { district }\end{array}$} & \multirow{2}{*}{$\begin{array}{c}\text { Agr } \\
\text { ozo } \\
\text { ne }\end{array}$} & \multirow{2}{*}{$\begin{array}{c}\text { Sowing } \\
\text { area } \\
\text { thousand } \\
\text { ha }\end{array}$} & \multicolumn{6}{|c|}{ Amount of combines, units } \\
\hline & & & $\begin{array}{c}\text { Flax- } \\
\text { pulling } \\
\text { machines }\end{array}$ & $\begin{array}{c}\text { Flax } \\
\text { threshe } \\
\text { r }\end{array}$ & Harvesters & $\begin{array}{l}\text { Agit } \\
\text { ator }\end{array}$ & $\begin{array}{c}\text { Turne } \\
\mathbf{r}\end{array}$ & Pickers \\
\hline Central & 1.1 & 160,07 & 1334 & 2508 & 3335 & 1214 & 1214 & 1547 \\
\hline $\begin{array}{l}\text { North- } \\
\text { western }\end{array}$ & 2 & 41,99 & 353 & 658 & 875 & 318 & 318 & 406 \\
\hline \multirow{3}{*}{$\begin{array}{l}\text { Privolzh } \\
\text { sky }\end{array}$} & 4.1 & 9,92 & 66 & 153 & 208 & 75 & 75 & 89 \\
\hline & 4.2 & 3,01 & 20 & 47 & 63 & 23 & 23 & 29 \\
\hline & 4.3 & 40,02 & 267 & 627 & 840 & 310 & 310 & 390 \\
\hline \multirow[t]{2}{*}{ Ural } & 5.1 & 0,28 & 2 & 4 & 6 & 2 & 2 & 3 \\
\hline & 5.2 & 0,28 & 2 & 4 & 6 & 2 & 2 & 3 \\
\hline Siberian & 6.2 & 44,09 & 301 & 665 & 911 & 353 & 353 & 423 \\
\hline $\begin{array}{l}\text { Russia } \\
\text { in } \\
\text { general }\end{array}$ & & 300,00 & 2325 & 4675 & 6250 & 2275 & 2275 & 2900 \\
\hline
\end{tabular}

Table 5 shows the predicted technological need for agricultural zones and Russia as a whole in specialized flax harvesting machines: flax-pulling machine, flax thresher, harvesters, agitator, turner, pickers

\section{Conclusions}

The forecasted technological need for specialized flax harvesting equipment has been determined: flax hammers - 2325 units, flax threshers - 4675 units, combines - 6250 units, tedders - 2275 units, turners - 2275 units, pickers - 2900 units. which will allow performing technological operations within the established agro-terms, and will ensure the production of the volume of flax fiber required for Russia. 


\section{Reference}

1. M.A. Smirnov, A.V. Lavrov, V.G. Shevtsov, On the need to restore mechanized agricultural production in Russia, National interests: priorities and security. Vol. 14.No. 1 (358). p. 48-61 (2018).

2 A.V. Lavrov, V.G. Shevtsov, V.A. Zubin, Analysis of the impact of the duration of agricultural operations on crop losses in the soil and climatic conditions of the Kaluga region, Proceedings: "Adaptive-landscape farming systems - the basis for the effective use of reclaimed land" Materials of the International Scientific and Practical Conference of FGBNU VNIIMZ.- Tver. p. 35-39 (2017).

3. Agro-industrial complex of Russia in 2018, Ministry of Agriculture of the Russian Federation, (2019).

4. Russia in numbers. 2020: Brief statistics collection, Rosstat-M., 550 p (2020).

5. Analytical review. Production of automobile, tractor, agricultural machinery and components to it by manufacturers in Russia and other CIS countries (Appendix to the magazine "Automobiles, tractors. CIS market), Avtoselkhozmashholding JSC Committee of the RF CCI on entrepreneurship in the automotive sector. - M., 2003, 2004, 2005, 2006, 2007, 2008, 2009, 2010, 2011, 2012, 2013, 2014, 2015, 2016, 2017, 2018, 2019.

6. Perspective resource-saving technology for the production of oil flax: method. Rivers, FGNU "Rosinformagrotech", 52 p (2010).

7. Beilis V.M. Duration of mechanized agricultural field work, "Publishing house VIM". $164 \mathrm{p}(2005)$.

8. A.Yu. Izmailov, V.P. Elizarov, N.M. Antyshev et al. Method of using conditional coefficients for converting tractors, grain and forage harvesters into reference units in determining the standards for their needs, FGNU "Rosiinformagrotech". 56p. (2009). 